\title{
PRIMEIRA OCORRÊNCIA DE FUSARIUM SOLANI EM OLIVEIRAS CULTIVADAS NO BRASIL
}

\author{
R.J. Domingues, J.G. Töfoli, S. Zanota, R. Harakava \\ Instituto Biológico, Centro de Pesquisa de Sanidade Vegetal, Av. Cons. Rodrigues Alves, 1252, \\ CEP 04014-900, São Paulo, SP, Brasil. E-mail: ricardo.domingues@sp.gov.br
}

\section{RESUMO}

Em cultivo de oliveiras localizado no município de Pilar do Sul, SP, foi verificada a presença de plantas com sintomas de seca de folhas e ramos, queda de vigor, podridão do sistema radicular e morte de plantas. Em alguns casos foi observada também a morte de apenas partes ou lados das plantas com a presença ou não de rebrota parcial da copa. Fungo com características morfológicas semelhantes a Fusarium solani, foi isolado a partir de amostras das plantas doentes compostas por ramos, folhas e raízes. Inoculações foram feitas em mudas sadias das cultivares Arbequina, Arbosana e Maria da Fé. A partir de 30 dias, as plantas inoculadas de todas as cultivares apresentaram sintomas de murcha, amarelecimento, queda das folhas e morte. O fungo foi re-isolado para a conclusão dos postulados de Koch. Em seguida, realizou-se a sua identificação molecular através da análise da região ITS do DNA ribossômico. As análises confirmaram o fungo $F$. solani como agente causal da doença. A identificação molecular foi $99 \%$ semelhante as estirpes de Fusarium solani (Mart.) Sacc. 1881 Kleb. 1913, isolados de cultivos de oliveiras com os mesmos sintomas e provenientes do Nepal e da Argentina. Trata-se do primeiro relato da doença nas condições brasileiras de cultivo.

PALAVRAS-CHAVE: Olea europaea, Neocosmospora solani, fusariose, oliva 


\section{ABSTRACT}

\section{FIRST REPORT OF FUSARIUM WILTIN BRAZILIAN CULTIVATED OLIVE TREES}

In a cultivation of olive trees in the municipality of Pilar do Sul, SP, were verified in 2015 , plants with symptoms of root rot and dry leaves, death of branches and plants, and death of only parts of plants or even whole, with regrowth cases with partial crown recovery. Fungus with morphological characteristics similar to F. solani, was isolated from samples of diseased plants composed of branches and leaves. Inoculations were made in healthy plants of the cultivars Arbequina, Arbosana and Maria da Fé. After 30 days, the inoculated plants of all cultivars showed symptoms of wilting, yellowing, leaf fall and death. The fungus was re-isolated to the conclusion of Koch's postulates. Then, its molecular identification was performed by analyzing the ITS region of ribosomal DNA. The analyzes confirmed the fungus $F$. solani as causal agent of the disease. Molecular identification was 99\% similar to Fusarium solani (Mart.) Sacc. 1881 Kleb. 1913, strains isolated from olive cultivars with the same symptoms and coming from Nepal and Argentina. This is the first report of the disease under Brazilian cultivation conditions.

KEY-WORDS: Olea europaea, Neocosmospora solani, fusariosis, olive 
A oliveira (Olea europaea L.) é uma planta originária do Oriente Médio onde, há cerca de 6.000 anos teve ínicio sua domesticação; cultivo e posterior difusão para outras áreas da bacia do Mediterrâneo. Nessa região, onde se concentram os maiores produtores mundiais, são colhidas cerca de 3,1 milhões de toneladas de frutos por ano, representando $95 \%$ da produção mundial, dos quais $73 \%$ desses são provenientes de países da União Europeia, como Espanha, Portugal, Itália, entre outros (COI, 2012). Nas Américas, o cultivo iniciou-se no período colonial, sendo observados os primeiros registros no México, no Peru e na Califórnia e, em seguida, em países com clima subtropical como Chile, Argentina e Uruguai.

No passado inúmeras tentativas de introdução e cultivo de oliveiras foram realizadas no Brasil, porém nem sempre bem sucedidas. Fatores relacionados a estes fracassos referem-se a: plantio de apenas um material genético; local de implantação da cultura inapropriado às suas necessidades; cultivar não adaptado às condições climáticas locais; pacote tecnológico não adaptado às condições de clima subtropical; dificuldades de manejo de cultura exótica em nossas condições, como adubação, poda, controle de pragas e doenças (BERTONCINI et al., 2010).

Apesar das dificuldades citadas, alguns bons resultados vêm sendo obtidos quando os plantios são conduzidos em microclimas favoráveis à cultura como é o caso do estado do Rio Grande do Sul e em algumas regiões da serra da Mantiqueira nos estados de Minas Gerais e São Paulo, com altitudes maiores que 1000 metros, além de áreas dos estados do Rio de Janeiro e Espirito Santo, Santa Catarina e Paraná. Nessas regiões a cultura vem se desenvolvendo rapidamente com a área plantada evoluindo de 1.500 hectares em 2014 para cerca de 7.000 hectares em 2017 (ANUARIO BRASILEIRO DAS OLIVEIRAS, 2018). Além dos já conhecidos efeitos benéficos para a saúde da dieta mediterrânea, outro fator considerado importante para o incentivo ao plantio da oliveira reside no fato do Brasil ser totalmente dependente de importação, tanto dos frutos para mesa quanto dos azeites, importando 86,5\% da Comunidade Econômica Européia, e $13,4 \%$ da Argentina, com gastos anuais em torno de 400 milhões de reais (BERTONCINI et al., 2010). Segundo dados do CONAB (2010), o Brasil vem aumentando ano após ano o volume de importação de azeitonas de mesa e azeite, uma elevação de demanda que pode representar uma oportunidade para os olivicultores brasileiros.

Apesar de apresentar certa rusticidade, a oliveira pode ser afetada por doenças das mais variadas etiologias. As doenças fúngicas estão entre as mais importantes, podendo causar desfolhas, queda de vigor, morte de plantas, lesões em frutos, apodrecimento e a queda de frutos (CASAS et al., 2012; DOMINGUES 
et al., 2016; TÖFOLI et al., 2013; TRAPERO et al, 2008; COUTINHO et al., 2009, MOEDANO; BERROCAL, 2011). Tais sintomas afetam diretamente o rendimento, a qualidade e o resultado econômico da atividade.

O genêro Fusarium foi descrito por Link em 1809, baseando-se na espécie tipo Fusarium roseum Link ex Fries, onde foram incluídas espécies com esporos fusiformes e formados em estroma. Em sua grande maioria, predominam parasitas facultativos de plantas, que habitam o solo em alguma fase de seu ciclo associados a matéria orgânica viva ou morta. O gênero Fusarium, de acordo com a classificação taxonômica, constitui um estado anamórfico da família Nectriaceae, ordem Hypocreales, filo Ascomycota (INDEX FUNGORUM, 2020). LOMBARD et. al., 2015, incluíram o complexo Fusarium solani (Mart.) Sacc.) no gênero Neocosmopora (Neocosmospora solani (Mart.) L. Lombard \& Crous), formada por patógenos cosmopolitas, capazes de infectar uma grande quantidade de espécies de plantas, principalmente árvores. Tais organismos caracterizamse por: nunca apresentarem pigmentação rósea, produzirem massas de esporos de cor marrom-claro, por formarem grande quantidade de microconídios e produzirem massas de macroconídios em esporodóquios na superfície de BCA (batata+cravo+agar) (LESLIE; SUMMERELL, 2006).
Os primeiros relatos da ocorrência de $F$. solani associado a oliveira foram feitos a partir de cultivos no Nepal e na Argentina. No caso nepalês, as plantas eram da cultivar "Leccino", com 1 a 2 anos de idade, oriundas da Europa e ainda estavam sendo mantidas em viveiro. Foram relatados sintomas de queda de folhas, murcha e morte de plantas (VETTRAINO et al., 2009). Na Argentina as plantas possuíam 10 anos de idade, eram da cultivar" Barnea" e as plantas exibiram alta incidência de podridão radicular, folhas secas, ramos mortos e plantas mortas (PEREZ et al., 2011).

Em cultivo conduzido no município de Pilar do Sul, SP, verificou-se, em agosto de 2015, plantas de 3 a 4 anos de idade das cultivares Arbosana, Maria da Fé, Ascolano, Koroneiki e Grapollo, com sintomas semelhantes aos acima descritos, além de morte de apenas partes das plantas ou até de um lado inteiro, com casos de rebrota com recuperação parcial da copa (Figs. 1 e 2).

Para a identificação do agente causal, amostras compostas por raízes, folhas e ponteiros de ramos com sintomas de secamento e morte foram coletadas, acondicionadas em sacos plásticos, identificadas e levadas para o laboratório para análise. Uma parte das amostras foi colocada em câmara úmida em $B O D$ a $24^{\circ} \mathrm{C}$, com fotoperíodo de 12 horas. A outra parte das amostras foi lavada em água corrente e em seguida 
foram retirados fragmentos do tecido procedendo a desinfestação superficial: os fragmentos foram submersos em álcool etílico a $70 \%$ por 30 segundos, em seguida foram transferidos para hipoclorito de sódio a 1:4 por 1 a 2 min e, posteriormente, lavados em água destilada para retirada do hipoclorito de sódio. Os fragmentos assim preparados foram plaqueados em meio ágar água (agar agar, Merck, $20 \mathrm{~g} / \mathrm{L}$ ) e BDA (meio pronto batata-dextrose-agar, Merck, $39 \mathrm{~g} / \mathrm{L})$ e incubados em BOD sob temperatura de $\pm 25^{\circ} \mathrm{C}$ e fotoperíodo de $12 \mathrm{~h}$.

Foi observada a presença de fungo com características morfológicas semelhantes a Fusarium sp. desenvolvendo-se nas amostras em câmara úmida. Foi realizado o isolamento direto do patógeno a partir da transferência das estruturas reprodutivas para meio de cultura e em seguida, a purificação da colônia através de repicagens sucessivas. Posteriormente, o fungo foi repicado para meio de folhas de cravo-ágar (CLA), preparados de acordo com FISHER et al. (1982), para indução de esporulação e caracterização morfológica. $O$ fungo foi repicado também para meio BDA para avaliação da pigmentação produzida.

A inoculação para confirmação da sua patogenicidade foi realizada em condições de casa de vegetação através de fixação de discos de $0,5 \mathrm{~cm}$ de agar água contendo micélio e esporos, na base de 3 mudas sadias de cada uma das cultivares Arbequina, Arbosana e
Maria da Fé, após a remoção de parte da casca com um estilete esterilizado. A área inoculada foi recoberta por uma bandagem plástica, a fim de proteger contra contaminações e para propiciar condições de câmara úmida. Outras 3 mudas sadias de cada cultivar foram inoculadas somente com disco de ágar água como controle.

A partir de 30 dias, apenas as plantas inoculadas com discos de agar água e estruturas do fungo, de todas as cultivares, apresentaram sintomas de murcha, amarelecimento, queda das folhas e morte (Fig. 3). O fungo foi reisolado para a conclusão dos postulados de Koch.

Esporodóquios de coloração creme, típicas de $F$. solani, foram verificadas apenas sobre os pedaços de folhas de cravo, quando o fungo foi cultivado em meio CLA (Fig. 4), onde foi possível a visualização de macroconídios contendo de 3 a 5 septos e levemente curvados (Fig. 5). Não foi observada produção de pigmentos quando cultivado em meio BDA, no entanto, houve abundante produção de clamidósporos (Fig. 6) e microconídios.

O DNA dos isolados foram extraídos do micélio conforme protocolo de DELLAPORTA et al. (1983) com modificações, onde o material foi triturado na presença de nitrogênio líquido dentro de microtubos de $1,5 \mathrm{~mL}$, foi adicionado $600 \mu \mathrm{l}$ de solução de extração CTAB. Os microtubos foram incubados por 30 minutos a $65^{\circ} \mathrm{C}$ com agitação moderada. 
Foi adicionado $600 \mu \mathrm{l}$ de clorofórmio/ álcool isoamílico (24:1). A fase aquosa foi transferida para novos tubos onde a etapa com clorofórmio/álcool isoamílico foi repetida. $O$ sobrenadante foi transferido para novos microtubos de $1,5 \mathrm{~mL}$, onde foi adicionado isopropanol e posteriormente incubados a $-4^{\circ} \mathrm{C}$ durante a noite. Após a incubação e centrifugação, o sobrenadante foi descartado. Adicionou-se $500 \mu \mathrm{l}$ de etanol $70 \%$, descartou o sobrenadante e o pellet seco a $36^{\circ} \mathrm{C}$ por 20 minutos. O DNA foi diluído em $30 \mu$ de água de osmose reversa estéril e armazenado a $-20^{\circ} \mathrm{C}$.

Para a caracterização taxonômica utilizaram-se os oligonucleotídeos iniciadores ITS1 (5'-TTC CGT AGG TGA ACC TGC GG-3') e ITS4 (5'-TCC TCC GCT TAT TGA TAT GC-3') (White et al., 1990). A reação da PCR totalizou $25 \mu \mathrm{L}$ contendo aproximadamente $1,5 \mu \mathrm{L}$ de DNA, 2,5 $\mu \mathrm{L}$ tampão $10 \mathrm{X}$ com $\mathrm{MgCl}_{2}, 0,5 \mu \mathrm{L}$ de Mix DNTP $10 \mu \mathrm{M}$, 1,0 de cada um dos oligonucleotídeos iniciadores $10 \mathrm{mM}, 0,2 \mu \mathrm{L}$ da enzima Taq polimerase (2 unidades) e $18,3 \mu \mathrm{L}$ água ultrapura para completar o volume da reação. As reações foram realizadas em termociclador sob as seguintes condições térmicas: $94{ }^{\circ} \mathrm{C}$ por $2 \mathrm{~min}, 30$ ciclos de $94{ }^{\circ} \mathrm{C}$ por $45 \mathrm{~s}, 55^{\circ} \mathrm{C}$ por $30 \mathrm{~s}$, $72{ }^{\circ} \mathrm{C}$ por $35 \mathrm{~s}$ e $72{ }^{\circ} \mathrm{C}$ por $10 \mathrm{~min}$. Ao final da reação, o produto foi mantido a $-4{ }^{\circ} \mathrm{C}$. Um controle negativo sem DNA foi incluído nas amplificações do PCR. Os fragmentos amplificados e o controle foram separados por eletroforese em gel de agarose 1,5\%, em tampão TAE 1X, contendo brometo de etídio, visualizado sob luz ultravioleta e fotografado através do fotodocumentador.

Os produtos da PCR foram purificados seguindo protocolo descrito por SCHMITZ; RIESNER (2006) e sequenciados pelo método de terminação de cadeia, descrito por SANGER et al. (1977).

As reações para sequenciamento foram efetuadas com o kit Big Dye 3.1 (Applied Biosystems) e analisadas em sequenciador $\mathrm{ABI} 3500 \mathrm{xL}$ (Applied Biosystems), conforme instruções do fabricante. As sequências obtidas foram alinhadas e analisadas utilizando-se o programa BioEdit (HALL, 1999). Após, as sequências obtidas foram comparadas com sequencias inseridas no GenBank, sediado no National Center for Biotechnology Information (NCBI) (http// www.ncbi.nlm.nih.gov) (ALTSCHUL et al., 1997).

As análises tanto morfológicas quanto moleculares, confirmaram o fungo Fusarium solani como agente causal da doença. A identificação molecular foi 99\% semelhante aos isolados do Nepal e da Argentina. Trata-se do primeiro relato da doença em oliveira nas condições brasileiras de cultivo. 


\section{REFERÊNCIAS}

ALTSCHUL, S. F.; MADDEN, T.L.; SCHÄFFER, A.A.; ZHANG, J.; ZHANG, J.; MILLER, W.; LIPMAN, D. J. Gapped BLAST and PSI-BLAST: a new generation of protein database search programs. Nucleic Acids Res. 1997;25(17):3389-3402. doi:10.1093/nar/25.17.3389

ANUARIO BRASILEIRO DAS OLIVEIRAS. 2018. Disponível em: http://www.editoragazeta.com.br/sitewp/wpcontent/uploads/2018/07/OLIVEIRAS_2018_DUPLA.pdf. Acesso em: 04/06/2020

BERTONCINI, E.I.; TERAMOTO, J.R.S; PRELA-PANTANO. Desafios para produção de azeite no Brasil. 2010. Artigo em Hypertexto. Disponível em: <http://www.infobibos.com/Artigos/2010_4/DesafioOliva/index.htm>. Acesso em: 9/6/2020

CASAS A.T.; CASTILLO L.F.R.; MORAL J.M.; RAMÍREZ C.T.; ESCUDERO F.J.L. Doenças da oliveira e seu controle. In: OLIVEIRA, A.F. Oliveira no Brasil: tecnologias de produção. Belo Horizonte: EPAMIG, 2012. p. 517-566.

COI - INTERNATIONAL OLIVE COUNCIL - http://www.internationaloliveoil.org/news/view/618-year-2011news/137-market-newsletter-april-2011. Acesso em: 13 de abril de 2013.

CONAB. Balança Comercial do Agronegócio. Brasília, 2010. Disponível em: http://www.conab.gov.br/ conabweb/download/indicadores/0206-balancaimportacao. pdf. Acesso em: 21 de julho 2010.

COUTINHO, E. F.; RIBEIRO, F. C.; CAPPELLARO , T. H. (Ed.). Cultivo de Oliveira (Olea europaea L.) Sistema de Produção 16 - Embrapa Clima Temperado, 2009. 125 p.

DELLAPORTA, S. L.; WOOD, J.; HICKS, J. B. A plant DNA minipreparation: version II. Plant Molecular Biology Reporter, v. 1, n. 4, p. 19-21, 1983.

DOMINGUES, R.J.; TÖFOLI, J.G.; FERRARI, J.T.; NOGUEIRA, E.M.C. 2016. Doenças fúngicas com potencial limitante para o desenvolvimento da olivicultura no Estado de São Paulo. Documento Técnico 24. Disponível em: http://www.biologico.sp.gov.br/uploads/docs/dt/fungos_oliveira.pdf . Acesso em: 15 de outubro de 2019 .

FISHER, N.L.; BURGESS, L.W.; TOUSSOUN, T.A.; NELSON, P.E. 1982. Carnation leaves a substrate for preserving cultures of Fusarium species. Phytopathology 72: 151-153.

INDEX FUNGORUM. Disponível em: http://www.indexfungorum.org/Names/Names.asp. Acesso em: 05/05/2020 $388 \mathrm{p}$.

LESLIE, J. F.; SUMMERELL, B. A. 2006. The Fusarium laboratory manual. 1. ed. USA: Blackwell Publishing.

LOMBARD, L.; VAN DER MERWE, N.A.; GROENEWALD, J.Z.; CROUS, P.W. 2015. Generic concepts in Nectriaceae. Stud. Mycol. 80: 189-245.

MOHEDANO D. P.; BERROCAL F. O. Producción Integrada de Olivar. Consejería de Agricultura y Pesca, Sevilla, 2011. $160 \mathrm{p}$.

NELSON, P.E.; TOUSSOUN, T.A. \& MARASAS, W.F.O. 1983. Fusarium species an ilustrated manual for identification. University Park: The Pennsylvania State University Press.

PEREZ, B.A.; FARINON, O.M.; BERRETTA, M.F. 2011. First report of Fusarium solani causing root rot of olive in Southeastern Argentina. PI. Dis. 95: 1476.

HALL, T.A. BioEdit: a user-friendly biological sequence alignment editor and analysis program for Windows 95/98/NT. Nucleic Acids Symposium Series, n. 41, p. 95-98, 1999.

SANGER, F., et al. DNA sequencing with chain-terminating inhibitors. Proceedings of the National Academy of Sciences, v. 74, p. 5463-5467, 1977.

SCHMITZ, A.; RIESNER, D. Purification of nucleic acids by seletive precipitation with polyethylene glycol 6000. Analytical Biochemistry, v.354, n. 02, p.311-313, 2006.

TÖFOLI, J.G.; DOMINGUES, R.J.; FERRARI, J.T.; NOGUEIRA, E.M.C. Doenças fúngicas da oliva: sintomas, etiologia e manejo. Biológico, São Paulo, v.75, n.1, p. 53-61, 2013.

TRAPERO, A.; BLANCO, M.A. Enfermedades. In: BARRAnco D., Fernandez-Escobar, R.; Rallo, L. El cultivo del olivo. 6. ed. Junta de Andalucía: Mundi-Prensa. p. 595-656, 2008.

VETTRAINO, A.M., SHRESTHA, G.P., AND VANNINI, A. 2009. First report of Fusarium solani causing wilt of Olea europaea in Nepal. PI. Dis. 93: 200.

WHITE TJ, BRUNS TD, LEE S, TAYLOR J. Amplification and direct sequencing of fungal ribosomal RNA genes for phylogenetics. In: Innis MA, Gelfand DH, Sninsky JJ, White TJ eds. PCR protocols, a guide to methods and applications. San Diego, California: Academic Press. P315-322, 1990.

Recebido em: 01/07/2020

Aprovado em: 18/09/2020 


\section{FIGURAS}

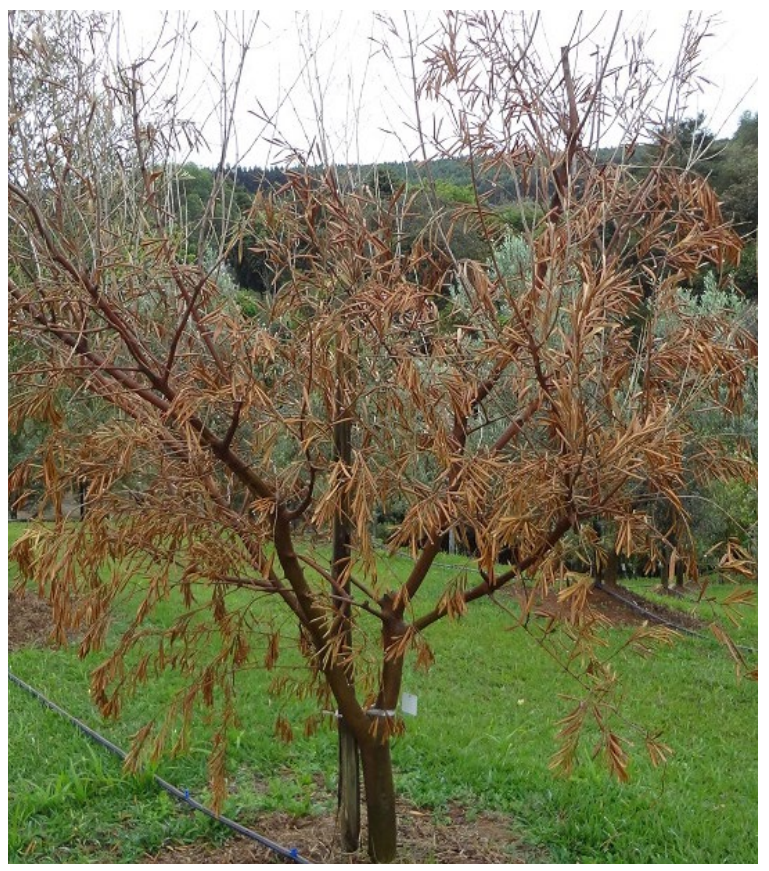

Figura 1: Oliveira (Olea europaea), cultivar Arbosana, apresentando sintomas de fusariose como seca de folhas e morte de ramos.

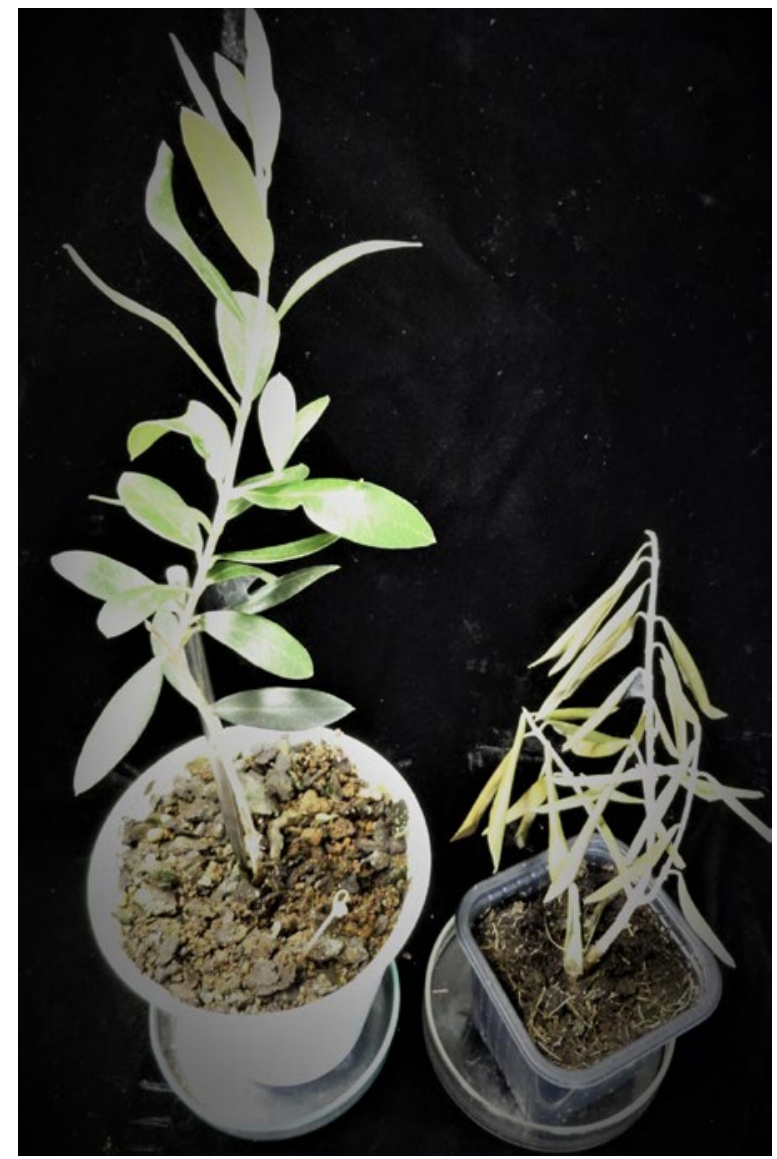

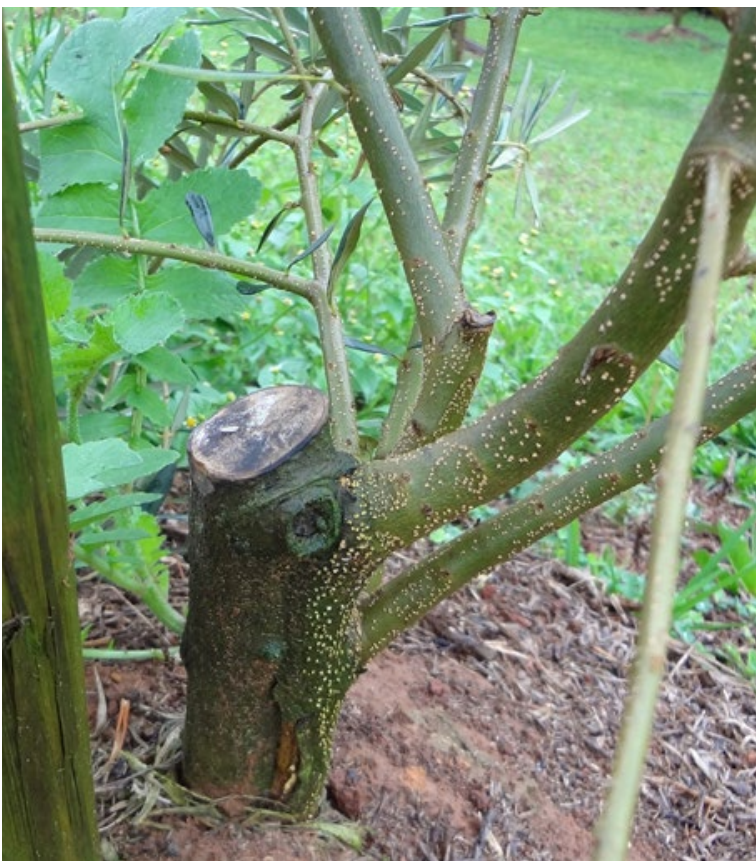

Figura 2: Oliveira (Olea europaea), cultivar Maria da Fé, apresentando sintomas de fusariose com morte de parte da copa e posterior rebrota.

Figura 3: Mudas de oliveiras cultivar Maria da Fé inoculada com $F$. solani (direita) e testemunha (esquerda) após 30 dias de incubação. 


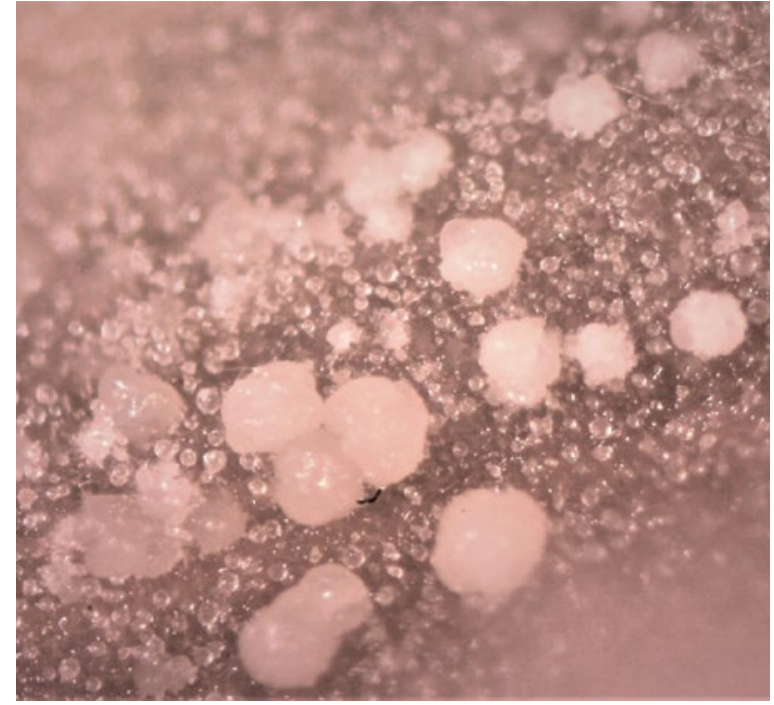

Figura 4: Esporodóquios de coloração creme, típicas de F. Solani, obtidos no cultivo em meio CLA.

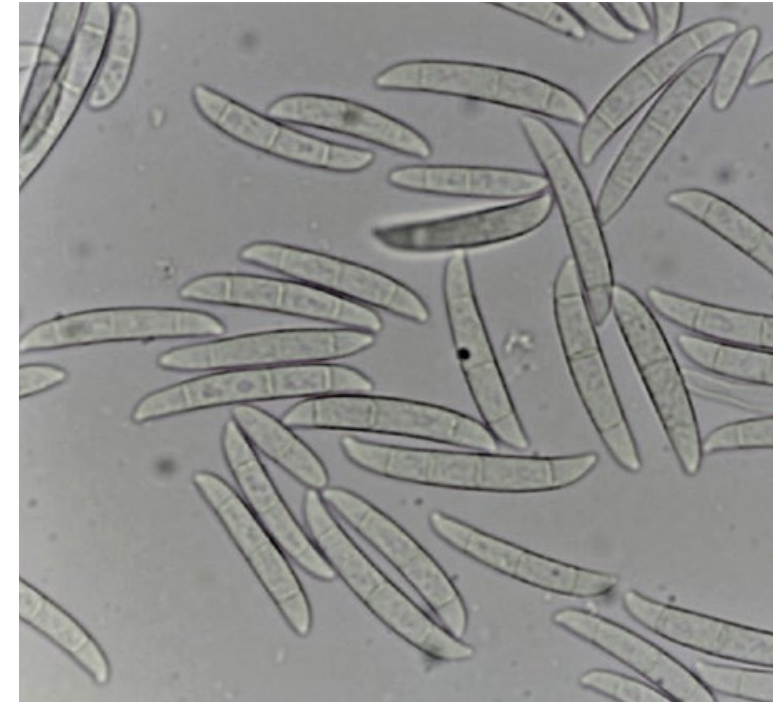

Figura 5: Macroconídios de F. solani contendo de 3 a 5 septos e levemente curvados, observados em cultivo em meio CLA.

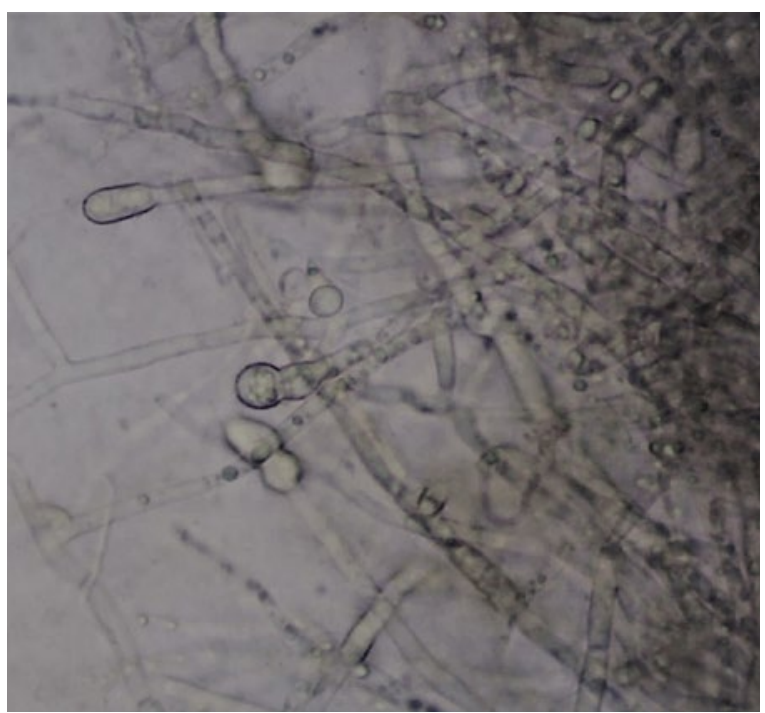

Figura 6: Clamidósporos de F. solani formados nos cultivos em meio BDA.

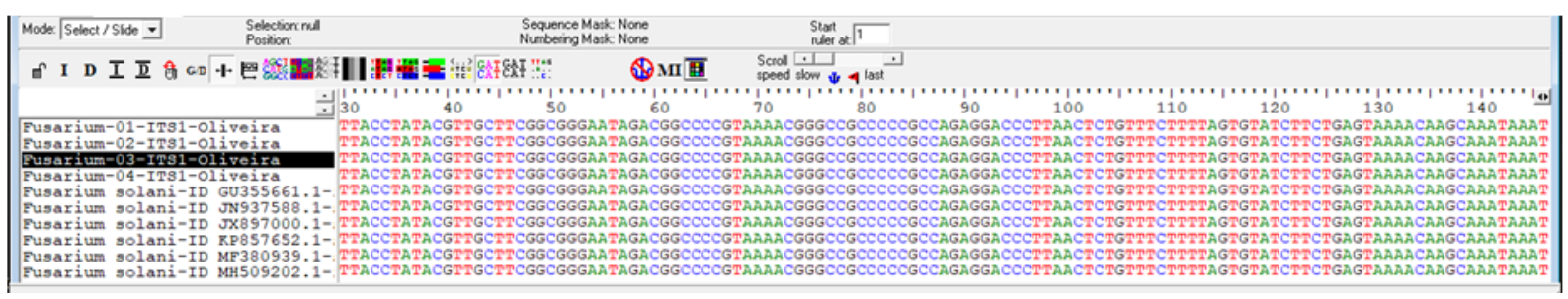

Figura 7: Interface do programa Bioedit onde com o alinhamento das sequências dos isolados de Fusarium sp. de oliveira obtidos neste trabalho com sequências de F. solani obtidos no NCBI (National Center for Biotechnology Information ). 